Y/DQ-51

\title{
Technical Basis for Beta Skin Dose Calculations at the Y-12 Plant
}

\author{
J. M. Thomas \\ R. S. Bogard \\ Health Physics Department \\ Health, Safety, Environment, and Accountability Division
}

March 1994

\author{
Prepared by the \\ Oak Ridge Y-12 Plant \\ Oak Ridge, Tennessee 37831-8169 \\ managed by \\ MARTIN MARIETTA ENERGY SYSTEMS, INC. \\ for the \\ U.S. DEPARTMENT OF ENERGY \\ under contract DE-AC05-84OR21400
}





\section{DISCLAIMER}

This report was prepared as an account of work sponsored by an agency of the United States Government. Neither the United States Government nor any agency thereof, nor any of their employees, makes any warranty, express or implied, or assumes any legal liability or responsibility for the accuracy, completeness, or usefulness of any information, apparatus, product, or process disclosed, or represents that its use would not infringe privately owned rights. Reference herein to any specific commercial product, process, or service by trade name, trademark, manufacturer, or otherwise, does not necessarily constitute or imply its endorsement, recommendation, or favoring by the United States Government or any agency thereof. The views and opinions of authors expressed herein do not necessarily state or reflect those of the United States Government or any agency thereof. 


\section{DISCLAIMER}

Portions of this document may be illegible in electronic image products. Images are produced from the best available original document. 


\section{CONTENTS}

LIST OF TABLES $\ldots \ldots \ldots \ldots \ldots \ldots \ldots \ldots \ldots \ldots \ldots \ldots \ldots \ldots \ldots \ldots \ldots$

ABSTRACT $\ldots \ldots \ldots \ldots \ldots \ldots \ldots \ldots \ldots \ldots \ldots \ldots \ldots \ldots \ldots \ldots \ldots \ldots$

INTRODUCTION $\ldots \ldots \ldots \ldots \ldots \ldots \ldots \ldots \ldots \ldots \ldots \ldots \ldots \ldots \ldots \ldots$

REQUIREMENTS FOR SKIN DOSE CALCULATION $\ldots \ldots \ldots \ldots \ldots \ldots \ldots \ldots$

VARSKIN COMPUTER CODE PARAMETERS $\ldots \ldots \ldots \ldots \ldots \ldots \ldots \ldots \ldots \ldots \ldots$

RADIONUCLIDE SELECTION $\ldots \ldots \ldots \ldots \ldots \ldots \ldots \ldots \ldots \ldots$

AREA DETERMINATION $\ldots \ldots \ldots \ldots \ldots \ldots \ldots \ldots \ldots \ldots \ldots \ldots$

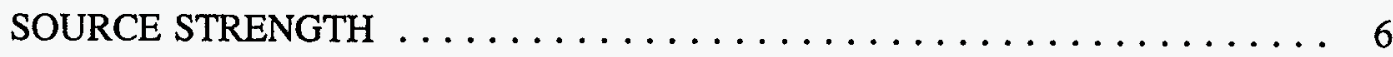

EXPOSURE TIME $\ldots \ldots \ldots \ldots \ldots \ldots \ldots \ldots \ldots \ldots \ldots \ldots \ldots \ldots$

SKIN THICKNESS $\ldots \ldots \ldots \ldots \ldots \ldots \ldots \ldots \ldots \ldots \ldots$

SUMMARY OF Y-12 PLANT SPECIFIC ASSUMPTIONS $\ldots \ldots \ldots \ldots \ldots \ldots \ldots \ldots$

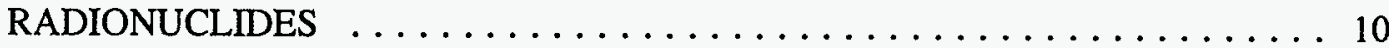

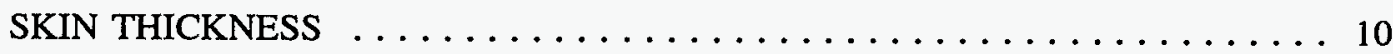

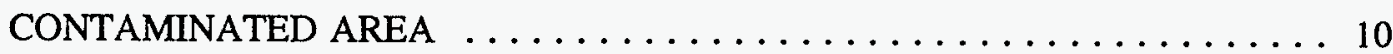

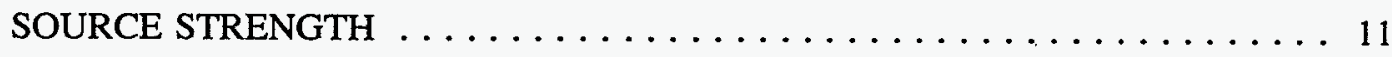

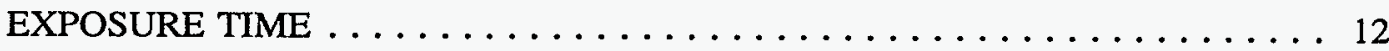

DERIVATION OF TRIGGER LEVELS FOR SKIN DOSE ASSESSMENT $\ldots \ldots \ldots \ldots 12$ DEPLETED-URANIUM CONTAMINATION MEASURED WITH A GM

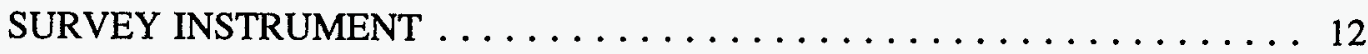

DEPLETED-URANIUM CONTAMINATION MEASURED WITH

A GAS PROPORTIONAL COUNTER SURVEY INSTRUMENT . . . . . . . . 13

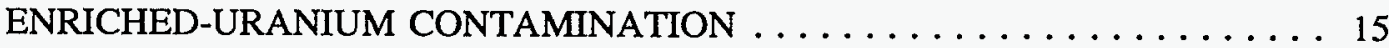

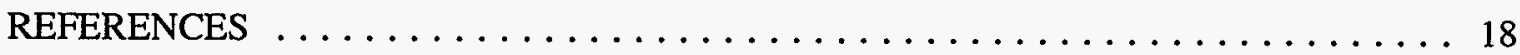

APPENDIX: SAMPLE VARSKIN DATA FILE $\ldots \ldots \ldots \ldots \ldots \ldots \ldots \ldots$ 


\section{LIST OF TABLES}

1 Recording requirements for nonuniform exposure of the skin

2 Decay data for beta-emitting radionuclides present in enriched and depleted uranium

3 Relative skin dose conversion factors for uranium daughters

4 Effects of contamination size on skin dose $\ldots \ldots \ldots \ldots \ldots \ldots \ldots \ldots$

5 Effects of contamination amount on skin dose $\ldots \ldots \ldots \ldots \ldots$

6 Effects of exposure duration on skin dose $\ldots \ldots \ldots \ldots \ldots \ldots \ldots$

7 Epidermal thickness for main body sites for males and females of ages 15 to 89 years $\ldots \ldots \ldots \ldots \ldots \ldots \ldots \ldots \ldots \ldots \ldots$

8 Typical density thicknesses of company-issued clothing $\ldots \ldots \ldots \ldots \ldots$

9 Guidelines for estimating the size of contaminated skin

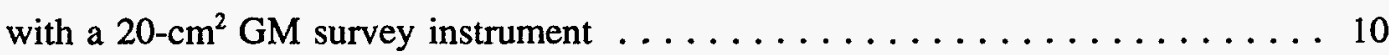

10 Guidelines for estimating the size of contaminated skin with a $100-\mathrm{cm}^{2}$ gas proportional counter survey instrument 


\begin{abstract}
This report describes the methods for determining shallow dose equivalent to workers at the Oak Ridge Y-12 Plant from skin contamination detected by survey instrumentation.

Included is a discussion of how the computer code VARSKIN is used to calculate beta skin dose and how the code input parameters affect skin dose calculation results. A summary of Y-12 Plant specific assumptions used in performing VARSKIN calculations is presented. Derivations of contamination levels that trigger the need for skin dose assessment are given for both enriched and depleted uranium with the use of Y-12 Plant site-specific survey instruments. Department of Energy recording requirements for nonuniform exposure of the skin are illustrated with sample calculations.
\end{abstract}




\section{INTRODUCTION}

The purpose of this document is to describe the methodology for calculating beta skin dose to workers at the Oak Ridge Y-12 Plant. Skin dose, or dose equivalent, from radioactive contamination on the surface of the skin at a depth of $70 \mu \mathrm{m}$ must be inferred from calculations. The computer code VARSKIN MOD 1 (ref. 1) is used to perform these calculations. This document reviews the input parameters necessary to calculate skin dose equivalent and provides the technical basis for all associated assumptions. Recommendations for practical levels of skin contamination at which dose assessment is initiated are also included.

\section{REQUIREMENTS FOR SKIN DOSE CALCULATION}

The U.S. Department of Energy Radiological Control Manual (referred to as the DOE RadCon Manual), Department of Energy (DOE) Notice N 5480.6, Article 541.5, requires that levels of skin contamination that trigger the need for dose assessment be established at levels not exceeding 100 mrem. At the Y-12 Plant, skin dose is assessed if the potential dose is 100 mrem or greater (which is $0.2 \%$ of the annual limit). A level of 1000 mrem was proposed in a draft revision to DOE Order 5480.11 (ref. 3), dated March 13, 1990, for reporting purposes, but this value has not been incorporated into official DOE orders. Currently, 10 CFR Pt. 835 (ref. 4) and DOE Order 5480.11 do not mention trigger levels for skin dose calculations.

Nonuniform exposures of the skin from $\mathrm{X}$ rays, beta radiation, and radioactive materials on the skin, including hot particles, shall be assessed and recorded as specified in the following documents:

1. DOE N 5480.6, U.S. Department of Energy Radiological Control Manual, Appendix 2C.

2. DOE Order 5480.11, "Radiation Protection for Occupational Workers," 9f2.

3. 10 CFR Pt. 835, "Radiation Protection for Occupational Workers," Sect. 205.

The regulatory requirements for recording skin dose are listed in Table 1. 
Table 1. Recording requirements for nonuniform exposure of the skin

\begin{tabular}{|c|c|}
\hline $\begin{array}{l}\text { Area of skin } \\
\text { irradiated }\end{array}$ & $\begin{array}{l}\text { (1) Method of ayeraging, (2) adding to other doses received, and } \\
\text { a (3) recording nonuniform skin dose }\end{array}$ \\
\hline$\geq 100 \mathrm{~cm}^{2}$ & $\begin{array}{l}\text { (1) Averaged over the } 100 \mathrm{~cm}^{2} \text { of skin receiving the maximum dose } \\
\text { (2) Added to any uniform dose equivalent also received by the skin } \\
\text { (3) Recorded as the annual extremity or skin (shallow) dose equivalent }(H)\end{array}$ \\
\hline$<100 \mathrm{~cm}^{2}$ & $\begin{array}{l}\text { (1) Averaged over the } 1 \mathrm{~cm}^{2} \text { of skin receiving the maximum dose }(D) \text {, } \\
\text { reduced by the fraction }(f) \text { that is the irradiated area in square } \\
\text { centimeters divided by } 100 \mathrm{~cm}^{2} \text { (i.e., } H=f D \text { ) } \\
\text { (2) Added to any uniform dose equivalent also received by the skin } \\
\text { (3) Recorded as the annual extremity or skin (shallow) dose equivalent }\end{array}$ \\
\hline$<10 \mathrm{~cm}^{2}$ & $\begin{array}{l}\text { (1) Averaged over the } 1 \mathrm{~cm}^{2} \text { of skin receiving the maximum dose } \\
\text { (2) Not added to any other dose equivalent, extremity, or shallow dose } \\
\text { equivalent (skin) recorded for the annual dose equivalent } \\
\text { (3) Recorded in a person's radiation dose record as a special entry }\end{array}$ \\
\hline
\end{tabular}

For example, if a person has contamination covering a $25-\mathrm{cm}^{2}$ area of the skin and the maximum dose to a $1-\mathrm{cm}^{2}$ area of that skin is reported by VARSKIN to be $50 \mathrm{mrem}$, the following dose would be reported:

$$
\mathrm{H}=f D,
$$

where

$H=$ reported skin (shallow) dose equivalent,

$f=$ irradiated area in square centimeters divided by $100 \mathrm{~cm}^{2}$,

$D=$ average dose to a $1-\mathrm{cm}^{2}$ area of skin receiving the maximum dose.

Therefore,

$$
\begin{aligned}
\text { Skin dose } H(\mathrm{mrem}) & =\frac{25 \mathrm{~cm}^{2}}{100 \mathrm{~cm}^{2}} 50 \mathrm{mrem} \\
& =12.5 \mathrm{mrem} .
\end{aligned}
$$


In addition, the DOE RadCon Manual lists the following requirements:

Article 541.7: Personnel with skin contamination for which dose assessment was not performed should be informed of the nature of the contamination and an upper estimate of the potential dose (such as less than $10 \mathrm{mrem}$ ) as soon as practicable, preferably prior to the end of the work day.

Article 541.8: An assessment of skin exposure requires time to conduct a detailed evaluation. Assessments shall be conducted ... and, promptly after completion, the results should be explained to the persons affected.

\section{VARSKIN COMPUTER CODE PARAMETERS}

VARSKIN is a computer code developed to estimate the radiation dose to the skin resulting from the spectrum of beta energies emitted from various radioactive contaminants on the skin. VARSKIN utilizes a method based on tables of absorbed energy distributions around point sources in water that were developed by M. J. Berger. ${ }^{5}$ The code has a library of 83 radioisotopes and allows dose computation at a specified depth from a source ranging in size from a point source to a $100-\mathrm{cm}^{2}$ disk.

The basic formula for skin dose calculation is

$$
\text { Dose equivalent }=\text { activity } \times \text { time } \times \text { dose conversion factor } .
$$

To calculate skin dose, the VARSKIN code requires the following information:

1. Radionuclide(s).

2. Skin thickness $(0.007 \mathrm{~cm}$ is the VARSKIN default).

3. Size of the contaminated area in square centimeters.

4. Source strength (input as either a total microcurie amount or a concentration in microcuries per square centimeter).

5. Exposure time (the amount of time the contamination was present on the skin).

After a dose calculation, VARSKIN stores pertinent information in a text data file that can be used to document dose assessments. The Appendix is a sample VARSKIN data file. 


\section{RADIONUCLIDE SELECTION}

The first step in determining skin dose by using the VARSKIN code is to select the appropriate radionuclides that contribute to skin dose. At the Y-12 Plant, depleted uranium is approximately $99.8 \%{ }^{238} \mathrm{U}$ and only $0.2 \%{ }^{235} \mathrm{U}$, and enriched uranium is approximately $93 \%$ ${ }^{235} \mathrm{U}, 6 \%{ }^{238} \mathrm{U}$, and $1 \%{ }^{234} \mathrm{U}$. Because of the isotopic percentages, skin dose from depleteduranium contamination will consider ${ }^{238} \mathrm{U}$ progeny, and skin dose from enriched-uranium contamination will consider ${ }^{235} \mathrm{U}$ and ${ }^{238} \mathrm{U}$ progeny. For the purpose of this document, all beta doses from ${ }^{238} \mathrm{U}$ are assumed to come from ${ }^{234 \mathrm{~m}} \mathrm{~Pa}$ and ${ }^{234} \mathrm{Th}$. All beta doses from ${ }^{235} \mathrm{U}$ are assumed to come from ${ }^{231} \mathrm{Th}$.

The beta emitters of interest from depleted uranium are ${ }^{234} \mathrm{Th}$ and ${ }^{234 \mathrm{~m}} \mathrm{~Pa}$ resulting from ${ }^{238} \mathrm{U}$ decay. Thorium-231 results from ${ }^{235} \mathrm{U}$ decay and is the primary source of beta dose for enriched uranium. Table 2 lists the parent radionuclides, maximum beta energies, and beta intensities for the beta-emitting radionuclides of interest. The primary skin dose hazard at the Y-12 Plant is from depleted uranium.

Table 2. Decay data for beta-emitting radionuclides present in enriched and depleted uranium

\begin{tabular}{|c|c|c|c|}
\hline $\begin{array}{l}\text { Parent } \\
\text { radiontictide }\end{array}$ & Beta-emitting & $\begin{array}{c}\text { Maximumbeta energy } \\
\text { (MeV) }\end{array}$ & $\begin{array}{l}\text { Beta intensity } \\
\quad(\%)\end{array}$ \\
\hline \multirow{3}{*}{${ }^{238} \mathrm{U}$} & ${ }^{234 \mathrm{~m}} \mathrm{~Pa}$ & 2.29 & 98 \\
\hline & \multirow{2}{*}{${ }^{234} \mathrm{Th}$} & 0.123 & 21 \\
\hline & & 0.193 & 79 \\
\hline${ }^{235} \mathrm{U}$ & ${ }^{231} \mathrm{Th}$ & 0.305 & 40 \\
\hline
\end{tabular}

Dose conversion factors are used to convert the activity levels of radionuclides on the skin to dose equivalent. Table 3 lists dose conversion factors calculated with VARSKIN for uranium progeny radionuclides. To illustrate the relative dose contribution, the dose conversion factors are calculated by using a $1-\mathrm{cm}^{2}$ contaminated area, a 10,000 disintegrations per minute (dpm) source strength, and a 1-h exposure duration.

Table 3. Relative skin dose conversion factors for uranium daughters

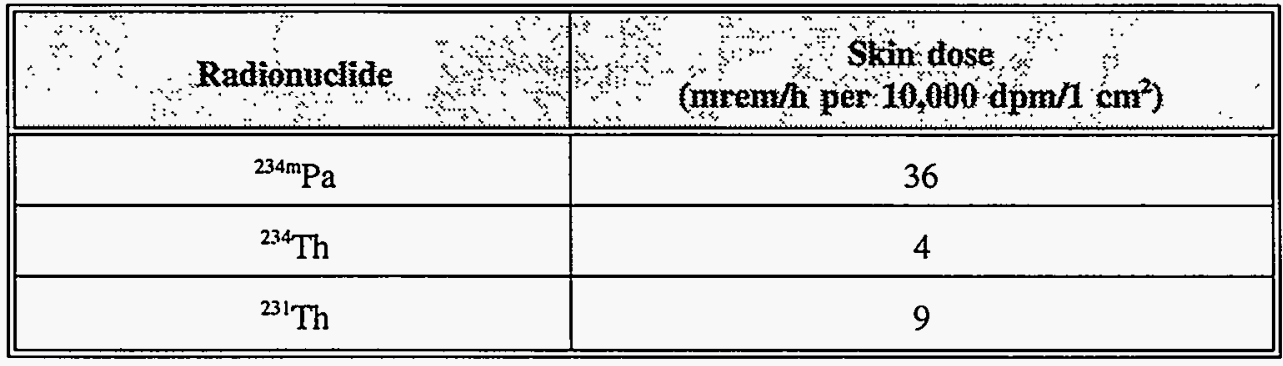


As can be seen from Table $3,{ }^{234 m} \mathrm{~Pa}$ contributes nine times the dose as an equal concentration of ${ }^{234} \mathrm{Th}$. Although ${ }^{231} \mathrm{Th}$ contributes 2.25 times the dose per unit exposure that ${ }^{234} \mathrm{Th}$ contributes, the activity of ${ }^{231} \mathrm{Th}$ in depleted uranium is approximately only $1 / 78$ that of ${ }^{234} \mathrm{Th}$ or ${ }^{234 \mathrm{~m}} \mathrm{~Pa}$. This ratio demonstrates the insignificance of including ${ }^{231} \mathrm{Th}$ in beta skin dose calculations for depleted uranium. Furthermore, enriched-uranium contamination is not a very significant source of skin dose.

\section{AREA DETERMINATION}

The second step in calculating skin dose is to input the size of the contaminated area. The Health Physics technician should make every effort to determine the actual area of the contaminated skin. Table 4 demonstrates how the size of the contaminated area affects the dose calculation for equal quantities of radioactivity. The data presented in Table 4 were obtained by using a 1 -h exposure time and a $0.007-\mathrm{cm}$ skin thickness.

Table 4. Effects of contamination size on skin dose

\begin{tabular}{|c|c|c|c|c|}
\hline Radionuclide & $\begin{array}{l}\text { Contamination } \\
\text { amoint (jCi) }\end{array}$ & $\begin{array}{l}\text { Contamination } \\
\text { area }\left(\mathrm{cm}^{2}\right)\end{array}$ & $\begin{array}{l}\text { Dose to affected } \\
\text { skin }^{*} \text { (mrem) }\end{array}$ & $\begin{array}{l}\text { Reported skin } \\
\text { dose (mrem) }\end{array}$ \\
\hline${ }^{234 \mathrm{~m}} \mathrm{~Pa}$ & 0.25 & 1 & 324 & 2020 \\
\hline${ }^{234 \mathrm{~m}} \mathrm{~Pa}$ & 0.25 & 5 & 151 & 458 \\
\hline${ }^{234 m} \mathrm{~Pa}$ & 0.25 & 10 & 98 & 23 \\
\hline${ }^{234 m} \mathrm{~Pa}$ & 0.25 & 20 & 58 & 23 \\
\hline${ }^{234 \mathrm{~m}} \mathrm{~Pa}$ & 0.25 & 25 & 50 & 23 \\
\hline${ }^{234 m} \mathrm{~Pa}$ & 0.25 & 50 & 29 & 23 \\
\hline${ }^{234 \mathrm{~m}} \mathrm{~Pa}$ & 0.25 & 75 & 21 & 23 \\
\hline${ }^{234} \mathrm{maa}$ & 0.25 & $100^{c}$ & 17 & 22 \\
\hline${ }^{234 \mathrm{~m}} \mathrm{~Pa}$ & 0.25 & 150 & 12 & 15 \\
\hline${ }^{234 m} \mathrm{~Pa}$ & 0.25 & 200 & 9 & 12 \\
\hline
\end{tabular}

"VARSKIN reports an area of skin where all cell damage occurs. "Dose to affected skin" is the skin dose averaged over this area.

bu "Reported skin dose" refers to the skin dose required to be reported to comply with DOE Order 5480.11 and DOE N 5480.6 (see p. 2).

'Current default area in use for calculations for 1990-1993.

As can be seen in Table 4, the dose to the affected skin area decreases as the radioactivity is distributed over larger areas. Currently at the Y-12 Plant, all skin contamination measurements are normalized to a $100-\mathrm{cm}^{2}$ area, with no determination of the actual size of contamination. International Commission on Radiological Protection Publication 26 (ref. 6) 
states that, for routine purposes, it is adequate to regard the contamination as being averaged over areas of $100 \mathrm{~cm}^{2}$. However, to calculate and report skin dose properly, the actual size of the contaminated area should be determined.

To measure beta/gamma skin contamination, the Y-12 Plant uses Geiger-Müller (GM) counters that have a $20-\mathrm{cm}^{2}$ detector surface area and gas proportional counters that have a $100-\mathrm{cm}^{2}$ detector surface area. In some instances, it may be difficult to accurately determine the size of a contaminated area when the area is less than the size of the detector surface area. In this case, the area of skin contamination should be assumed to be the size of the surface area of the detector. Nevertheless, every effort should be made to determine the actual size of the contaminated area.

\section{SOURCE STRENGTH}

Once the size of the contaminated area is known, either the total amount of radioactivity present or the concentration of radioactivity must be ascertained. To be conservative, the maximum contamination level obtained with a field instrument should be used. Unless information indicates otherwise, this maximum contamination level is assumed to be uniformly distributed and representative of the contamination levels of the entire affected area. Table 5 presents VARSKIN data obtained by varying contamination amounts distributed over a $20-\mathrm{cm}^{2}$ area. VARSKIN allows the user to input either total activity (i.e., $\mu \mathrm{Ci}$ ) or activity per unit area (i.e., $\mu \mathrm{Ci} / \mathrm{cm}^{2}$ ).

Table 5. Effects of contamination amount on skin dose

\begin{tabular}{|c|c|c|c|c|}
\hline Radionuclide & $\begin{array}{l}\text { Contamination } \\
\text { amount } \\
(\text { pCf(cm })\end{array}$ & $\begin{array}{l}\text { Contamination } \\
\text { area }\left(\mathrm{cm}^{2}\right)^{-}\end{array}$ & $\begin{array}{l}\text { Dose to } \\
\text { affected skin } \\
\text { (mirem) }\end{array}$ & $\begin{array}{l}\text { Reported skin } \\
\text { dose }^{b} \text { (nremi) }\end{array}$ \\
\hline${ }^{234 m} \mathrm{~Pa}$ & 0.001 & 20 & 5 & 1 \\
\hline${ }^{234 \mathrm{~m}} \mathrm{~Pa}$ & 0.002 & 20 & 9 & 2 \\
\hline${ }^{234 \mathrm{~m}} \mathrm{~Pa}$ & 0.005 & 20 & 23 & 5 \\
\hline${ }^{234 \mathrm{~m}} \mathrm{~Pa}$ & 0.0075 & 20 & 35 & 7 \\
\hline${ }^{234 \mathrm{~m}} \mathrm{~Pa}$ & 0.010 & 20 & 47 & 9 \\
\hline${ }^{234 \mathrm{~m}} \mathrm{~Pa}$ & 0.015 & 20 & 70 & 14 \\
\hline${ }^{234 m} \mathrm{~Pa}$ & 0.020 & 20 & 94 & 19 \\
\hline
\end{tabular}

${ }^{\circ}$ VARSKIN reports an area of skin where all cell damage occurs. "Dose to affected skin" is the skin dose averaged over this area.

${ }^{b c}$ Reported skin dose" refers to the skin dose required to be reported to comply with DOE Order 5480.11 and DOE N 5480.6 
As Table 5 demonstrates, the skin dose increases linearly with contamination amount when all other variables are constant. This is true for both the affected-skin calculations (column 4) and the reported-dose calculations (column 5).

\section{EXPOSURE TIME}

The next variable required for skin dose calculation is the duration of exposure, or the time the radioactive contamination was in contact with the skin. This information may be available from the contaminated worker. If the time at which the skin actually became contaminated is unknown, the Health Physics technician should assume that the contamination has been present on the skin since the person last began working with radioactive material (or entered a contaminated area) or since the last time a personnel contamination survey was conducted (either by Health Physics personnel or upon egress from a contaminated area). After each successive washing and resurvey, a separate dose calculation should be performed for each activity duration as appropriate. Judgment should be used in determining the appropriate exposure duration and whether additional dose calculations are needed. To perform this calculation, the technician must record the time of each survey and each decontamination effort.

Table 6 demonstrates how exposure duration affects skin dose calculation. The data for Table 6 were obtained by assuming a $0.01-\mu \mathrm{Ci} / \mathrm{cm}^{2}$ contamination concentration uniformly distributed over a $20-\mathrm{cm}^{2}$ area for various exposure durations and a $0.007-\mathrm{cm}$ skin thickness.

Table 6. Effects of exposure duration on skin dose

\begin{tabular}{|c|c|c|c|c|c|}
\hline Radionuclide & $\begin{array}{c}\text { Contamination: } \\
\text { amomnt } \\
\text { (nCi/cmi })\end{array}$ & $\begin{array}{c} \\
\text { Contamination } \\
\text { area }\left(\mathrm{cm}^{2}\right) \\
\vdots\end{array}$ & $\begin{array}{l}\text { Exposure } \\
\text { duration } \\
\text { (min) } \\
\text { (min }\end{array}$ & $\begin{array}{l}\text { Dose to } \\
\text { affected skin } \\
\quad \text { (mrem) } \\
\because \therefore \therefore \because\end{array}$ & $\begin{array}{c}\text { Repirted } \\
\text { skin } \\
\text { dose } \\
\text { (mrem) } \\
\ddots\end{array}$ \\
\hline${ }^{234 \mathrm{~m}} \mathrm{~Pa}$ & 0.010 & 20 & 15 & 12 & 4.6 \\
\hline${ }^{234 \mathrm{~m}} \mathrm{~Pa}$ & 0.010 & 20 & 30 & 23 & 9.2 \\
\hline${ }^{234 m} \mathrm{~Pa}$ & 0.010 & 20 & 45 & 35 & 13.8 \\
\hline${ }^{234 \mathrm{~m}} \mathrm{~Pa}$ & 0.010 & 20 & 60 & 47 & 18.4 \\
\hline${ }^{234 \mathrm{~m}} \mathrm{~Pa}$ & 0.010 & 20 & 90 & 70 & 27.6 \\
\hline${ }^{234 \mathrm{~m}} \mathrm{~Pa}$ & 0.010 & 20 & 120 & 94 & 36.8 \\
\hline${ }^{234 \mathrm{~m}} \mathrm{~Pa}$ & 0.010 & 20 & 180 & 140 & 55.2 \\
\hline
\end{tabular}

${ }^{a}$ VARSKIN reports an area of skin where all cell damage occurs. "Dose to affected skin" is the skin dose averaged over this area.

b"Reported skin dose" refers to the skin dose required to be reported to comply with DOE Order 5480.11 and DOE N 5480.6. 
As demonstrated in Table 6 , the skin dose is directly proportional to exposure duration when all other variables are constant.

\section{SKIN THICKNESS}

The VARSKIN default skin thickness of $0.007 \mathrm{~cm}$ should be used for routine dose assessments. Table 7 lists some alternate skin thicknesses provided by the International Commission on Radiological Protection ${ }^{7}$ that can be substituted when appropriate.

Table 7. Epidermal thickness for main body sites for males and females of ages 15 to 89 years

\begin{tabular}{||l|c|}
\hline \hline & Mody site \\
\hline Head & $0.0050 \pm 0.0022$ \\
\hline Trunk & $0.0043 \pm 0.0013$ \\
\hline Arms and legs & $0.0060 \pm 0.0002$ \\
\hline Back of hands & $0.0085 \pm 0.0026$ \\
\hline Wrists & $0.0080 \pm 0.0002$ \\
\hline Fingers & $0.0220 \pm 0.0120$ \\
\hline Fingertips & $0.0370 \pm 0.0112$ \\
\hline
\end{tabular}

As stated, the default input for skin thickness is $0.007 \mathrm{~cm}$. For situations involving contamination on clothing, several things must be considered in skin dose calculation. Because many of the ${ }^{234 \mathrm{~m}} \mathrm{~Pa}$ and ${ }^{234} \mathrm{Th}$ betas will be attenuated by clothing, this must be taken into account during dose assessment. One method of doing this is to increase the default skin thickness in VARSKIN to include clothing attenuation. However, this method is not justified if the contamination has penetrated or absorbed into the clothing and could be in contact with the skin. The best method is to measure the contamination levels on the inside of the clothing that contacts the skin. This directly accounts for clothing attenuation and allows the use of the VARSKIN default skin thickness. If clothing contamination exceeds regulatory contamination limits, the clothing must be removed for disposal; the appropriate inner surfaces can then be surveyed.

If the contamination has not penetrated/absorbed into the clothing facing the skin, the skin thickness can be increased to account for the beta attenuation of the clothing. To include the thickness of clothing in the skin thickness parameter, the following equations can be used: 
Equivalent skin thickness $(\mathrm{cm})=$ equivalent skin thickness from clothing $(\mathrm{cm})$

+ VARSKIN default skin thickness (cm),

and

Equivalent skin thickness from clothing $(\mathrm{cm})=$ VARSKIN default skin thickness $(\mathrm{cm})$

$$
\times \frac{\text { clothing density thickness }\left(\mathrm{mg} / \mathrm{cm}^{2}\right)}{\text { default skin density thickness }\left(\mathrm{mg} / \mathrm{cm}^{2}\right)} \text {. }
$$

The resulting equation is

Equivalent skin thickness $(\mathrm{cm})=0.007 \mathrm{~cm} \frac{\text { clothing density thickness }\left(\mathrm{mg} / \mathrm{cm}^{2}\right)}{7 \mathrm{mg} / \mathrm{cm}^{2}}+0.007 \mathrm{~cm}$,

where a $0.007-\mathrm{cm}$ skin thickness is assumed.

For other skin thicknesses, the following equation is used:

$$
\text { Equivalent skin thickness }(\mathrm{cm})=A \mathrm{~cm} \frac{\text { clothing density thickness }\left(\mathrm{mg} / \mathrm{cm}^{2}\right)}{B \mathrm{mg} / \mathrm{cm}^{2}}+A \mathrm{~cm} \text {, }
$$

where $A$ is skin thickness in centimeters and $B$ equals 1000 times the skin thickness in centimeters (density of skin $\approx 1000 \mathrm{mg} / \mathrm{cm}^{3}$ ).

Table 8 lists some known values for clothing density thickness. ${ }^{8}$

\begin{tabular}{|c|c|c|}
\hline Item & $\begin{array}{l}\text { Density thickness } \\
\left(\mathbf{m g} / \mathrm{cm}^{2}\right)^{-}\end{array}$ & Comments \\
\hline \multirow{2}{*}{ Men's pants } & 30 & New \\
\hline & 27 & Washed many times \\
\hline Men's shirt & 21 & \\
\hline Women's blouse & 13 & \\
\hline
\end{tabular}

Table 8. Typical density thicknesses of company-issued clothing 


\section{SUMMARY OF Y-12 PLANT SPECIFIC ASSUMPTIONS}

To estimate a conservative skin dose from beta/gamma skin contamination at the Y-12 Plant, the assumptions given in this section should be incorporated into routine VARSKIN calculations.

\section{RADIONUCLIDES}

The beta skin dose from depleted uranium should consider only the contributions from ${ }^{234 \mathrm{~m}} \mathrm{~Pa}$ and ${ }^{234} \mathrm{Th}$ in secular equilibrium.

\section{SKIN THICKNESS}

The VARSKIN default skin thickness of $0.007 \mathrm{~cm}$ should be used for situations in which the skin thickness is unknown. When appropriate, the skin thickness values given in Table 7 may be used.

\section{CONTAMINATED AREA}

If possible, the actual size of the contaminated area should be determined. If the exact size of the contaminated area cannot be accurately determined, the guidelines outlined in Table 9 should be used for measurement with Y-12 GM survey instruments (i.e., GM counters with associated electronic equipment).

Table 9. Guidelines for estimating the size of contaminated skin with a $20-\mathrm{cm}^{2} \mathrm{GM}$ survey instrument

\begin{tabular}{|l|l|}
\hline \multicolumn{1}{|c|}{ Contaminated area } & \\
\hline $\begin{array}{l}\text { Smaller than the size of the probe } \\
\left(<20 \mathrm{~cm}^{2}\right)\end{array}$ & Assume that the contaminated area of the skin is $20 \mathrm{~cm}^{2}$ \\
\hline $\begin{array}{l}\text { Larger than the size of the probe } \\
\left(>20 \mathrm{~cm}^{2}\right)\end{array}$ & Assume that the contaminated area of the skin is $100 \mathrm{~cm}^{2}$ \\
\hline Larger than $100 \mathrm{~cm}^{2}$ & $\begin{array}{l}\text { Estimate the contaminated area of the skin as closely as } \\
\text { possible }\end{array}$ \\
\hline
\end{tabular}


If a gas proportional counter with a $100-\mathrm{cm}^{2}$ detector surface area is used to determine the size of the contaminated area, the guidelines outlined in Table 10 should be used.

Table 10. Guidelines for estimating the size of contaminated skin with a $100-\mathrm{cm}^{2}$ gas proportional counter survey instrument

\begin{tabular}{||l|l||}
\hline \multicolumn{1}{|c|}{ Contaminated area } & \multicolumn{1}{|c||}{ Guidelines for estimating contaminated area } \\
\hline $\begin{array}{l}\text { Smaller than the size of the probe } \\
\left(<100 \mathrm{~cm}^{2}\right)\end{array}$ & Assume that the contaminated area of the skin is $100 \mathrm{~cm}^{2}$ \\
\hline $\begin{array}{l}\text { Larger than the size of the probe } \\
\left(>100 \mathrm{~cm}^{2}\right)\end{array}$ & $\begin{array}{l}\text { Estimate the contaminated area of the skin as closely as } \\
\text { possible }\end{array}$ \\
\hline
\end{tabular}

\section{SOURCE STRENGTH}

When the Health Physics technician is reporting the contamination source strength, the maximum disintegration rate obtained from the survey instrument should be given. This number will be the maximum net counts per minute (cpm) seen with the survey instrument during survey of the skin, divided by the instrument detection efficiency. If the technician normalizes the activity to $100 \mathrm{~cm}^{2}$, this information must then be provided to the dosimetrist, along with the size of the contaminated area.

For the GM survey instruments at the Y-12 Plant, a 16.7\% efficiency is assumed. To obtain the disintegration rate from the instrument count rate, the count rate should be multiplied by $6(1 \div 0.167)$ and the result reported in disintegrations per minute. Because the Y-12 Plant's GM counters have a window with a $1.7-\mathrm{mg} / \mathrm{cm}^{2}$ density thickness as well as a plastic "alpha discriminator" with approximately a $7-\mathrm{mg} / \mathrm{cm}^{2}$ density thickness, the beta emissions from ${ }^{234} \mathrm{Th}$ cannot penetrate into the active area of the detector. Therefore, the disintegration rate obtained from the GM counter is the disintegration rate for ${ }^{234 m} \mathrm{~Pa}$ only.

The gas proportional counters in use at $\mathrm{Y}-12$ have a window density thickness of only 0.9 $\mathrm{mg} / \mathrm{cm}^{2}$ (an alpha efficiency of approximately $20 \%$ and a ${ }^{90} \mathrm{Sr}$ beta efficiency of approximately $44 \%$ ). This window density thickness will allow entry and detection of both the ${ }^{234} \mathrm{Th}$ betas and the ${ }^{234 \mathrm{~m}} \mathrm{~Pa}$ beta. Therefore, the disintegration rate obtained from the gas proportional counter is the sum of the disintegration rates of both ${ }^{234} \mathrm{Th}$ and ${ }^{234 \mathrm{~m}} \mathrm{~Pa}$. As can be seen, it is important to note the type of instrument used to measure the level of skin contamination. (Gas proportional counters measure either alpha radiations only or alpha and beta radiations together. The beta activity must be obtained by subtracting the disintegration rate at the "alpha" operating voltage from the disintegration rate obtained at the "alpha + beta" operating voltage.) 


\section{EXPOSURE TIME}

The exposure time should be recorded by using conservative but reasonable estimates. As previously stated, if the time at which the skin became contaminated is unknown, the technician should assume that the contamination has been present on the skin since the person last began working with radioactive material (or entered a contaminated area) or since the last time a personnel contamination survey was conducted (either by Health Physics personnel or upon egress from a contaminated area). Judgment should be used in determining the appropriate exposure duration. After each successive decontamination effort, the remaining contamination level, as well as the exposure duration at that level, must be recorded. This is best achieved by recording the time of each survey and each decontamination effort.

\section{DERIVATION OF TRIGGER LEVELS FOR SKIN DOSE ASSESSMENT}

\section{DEPLETED-URANIUM CONTAMINATION MEASURED WITH A GM SURVEY INSTRUMENT}

The DOE RadCon Manual, Article 541.5 (ref. 2), states that the levels of skin contamination that trigger the need for dose assessments should be established for site-specific radionuclides and that these trigger levels should not exceed $100 \mathrm{mrem}$. In order to establish these trigger levels, several assumptions must be made. The following tabulation lists assumptions that will be used to determine the 100-mrem skin-dose-assessment trigger level for depleted-uranium skin contamination measured with a GM survey instrument at the Y-12 Plant:

Radionuclide

Skin thickness

Size of contaminated area

Exposure time

VARSKIN dose conversion factors for a $20-\mathrm{cm}^{2}$ contaminated area with the dose averaged over a $1-\mathrm{cm}^{2}$ area
${ }^{234 \mathrm{~m}} \mathrm{~Pa}$ and ${ }^{234} \mathrm{Th}$ (in equilibrium)

(Note: Only ${ }^{234 \mathrm{~m}} \mathrm{~Pa}$ betas are detected with the $\mathrm{Y}-12$ Plant GM survey instrument.)

$0.007 \mathrm{~cm}$

$20 \mathrm{~cm}^{2}$

$2 \mathrm{~h}$

${ }^{234 \mathrm{~m}} \mathrm{~Pa}: 21 \mathrm{mrem} / \mathrm{h}$ per $100,000 \mathrm{dpm}$

${ }^{234} \mathrm{Th}: 2 \mathrm{mrem} / \mathrm{h}$ per $100,000 \mathrm{dpm}$ 
Hence, for equal amounts of activity covering $20 \mathrm{~cm}^{2}$, the dose resulting from the ${ }^{234 \mathrm{~m}} \mathrm{~Pa}$ beta is 10.25 times that of the ${ }^{234} \mathrm{Th}$ betas. Therefore, if ${ }^{234 \mathrm{~m}} \mathrm{~Pa}$ and ${ }^{234} \mathrm{Th}$ are present in equal amounts and deliver a combined dose of $100 \mathrm{mrem}$, the contribution from the ${ }^{234 \mathrm{~m}} \mathrm{~Pa}$ beta must be approximately $91 \mathrm{mrem}$ and that from the ${ }^{234} \mathrm{Th}$ betas about $9 \mathrm{mrem}$. To incorporate the reporting requirements of DOE Order 5480.11 and DOE N 5480.6 into the trigger level for a $20-\mathrm{cm}^{2}$ contaminated area, the dose averaged over the $1 \mathrm{~cm}^{2}$ of skin receiving the maximum dose must be reduced by the fraction $(f)$ that is the size of the contaminated area divided by $100 \mathrm{~cm}^{2}$. Therefore,

$$
\text { Reported dose of } 91 \mathrm{mrem} \text { of }{ }^{234 \mathrm{~m}} \mathrm{~Pa}=\text { dose averaged over } 1 \mathrm{~cm}^{2} \frac{20 \mathrm{~cm}^{2}}{100 \mathrm{~cm}^{2}} \text {, }
$$

and

$$
\text { Dose averaged over } 1 \mathrm{~cm}^{2}=\frac{\text { reported dose of } 91 \mathrm{mrem}}{0.2}=455 \mathrm{mrem}
$$

The contamination trigger level corresponding to a $455-\mathrm{mrem}{ }^{234 \mathrm{~m}} \mathrm{~Pa}$ skin dose averaged over a $1-\mathrm{cm}^{2}$ area $\left(20-\mathrm{cm}^{2}\right.$ contaminated skin area) is

$$
\begin{aligned}
\text { Trigger level } & =\frac{\text { dose averaged over } 1 \mathrm{~cm}^{2} \text { of skin }}{\text { exposure duration }(\mathrm{h}) \times \text { dose conversion factor }(\mathrm{mrem} / \mathrm{h} \text { per } 100,000 \mathrm{dpm})} \\
& =\frac{455 \mathrm{mrem}}{2 \mathrm{~h} \frac{21 \mathrm{mrem} / \mathrm{h}}{100,000 \mathrm{dpm}}} \\
& =1,083,333 \mathrm{dpm} .
\end{aligned}
$$

With the use of the previously defined assumptions, the contamination level that will correspond to a 100-mrem skin dose, reported with a GM survey instrument, is $1,083,333 \mathrm{dpm}$ of ${ }^{234 \mathrm{~m}} \mathrm{~Pa}$ beta activity.

\section{DEPLETED-URANIUM CONTAMINATION MEASURED WITH A GAS PROPORTIONAL COUNTER SURVEY INSTRUMENT}

A list of assumptions that will be used to determine the 100-mrem skin-dose-assessment trigger level for depleted-uranium skin contamination measured with a gas proportional counter at the Y-12 Plant follows. 
Radionuclide

Skin thickness

Size of contaminated area

Exposure time

VARSKIN dose conversion factors for a $100-\mathrm{cm}^{2}$ contaminated area with the dose averaged over a $1-\mathrm{cm}^{2}$ area
${ }^{234 \mathrm{~m}} \mathrm{~Pa}$ and ${ }^{234} \mathrm{Th}$ (in equilibrium)

(Note: Both ${ }^{234 \mathrm{mPa}} \mathrm{Petas}$ and ${ }^{234} \mathrm{Th}$ betas are detected with the Y-12 Plant gas proportional counter survey instrument.)

$0.007 \mathrm{~cm}$

$100 \mathrm{~cm}^{2}$

$2 \mathrm{~h}$

${ }^{234 \mathrm{~m}} \mathrm{~Pa}: 41 \mathrm{mrem} / \mathrm{h}$ per $1,000,000 \mathrm{dpm}$

${ }^{234} \mathrm{Th}: 4 \mathrm{mrem} / \mathrm{h}$ per $1,000,000 \mathrm{dpm}$

${ }^{234 \mathrm{~m}} \mathrm{~Pa}+{ }^{234} \mathrm{Th}: 45 \mathrm{mrem} / \mathrm{h}$ per $2,000,000 \mathrm{dpm}$

To incorporate the reporting requirements of DOE Order 5480.11 and DOE N 5480.6 into the trigger level for a $100-\mathrm{cm}^{2}$ contaminated area, the dose averaged over the $1 \mathrm{~cm}^{2}$ of skin receiving the maximum dose must be reported. Therefore,

Dose averaged over $1 \mathrm{~cm}^{2}=100 \mathrm{mrem}$.

The contamination trigger level corresponding to a $100-\mathrm{mrem}{ }^{234 \mathrm{~m}} \mathrm{~Pa}+{ }^{234} \mathrm{Th}$ skin dose averaged over a $1-\mathrm{cm}^{2}$ area $\left(100-\mathrm{cm}^{2}\right.$ contaminated skin area) is

$$
\begin{aligned}
\text { Trigger level } & =\frac{\text { dose averaged over } 1 \mathrm{~cm}^{2} \text { of skin }}{\text { exposure duration }(\mathrm{h}) \times \text { dose conversion factor }(\mathrm{mrem} / \mathrm{h} \text { per } 2,000,000 \mathrm{dpm})} \\
& =\frac{100 \mathrm{mrem}}{2 \mathrm{~h} \frac{45 \mathrm{mrem} / \mathrm{h}}{2,000,000 \mathrm{dpm}}} \\
& \approx 2,220,000 \mathrm{dpm} .
\end{aligned}
$$


With the use of the previously defined assumptions, the contamination level that will correspond to a 100 -mrem skin dose, reported with a gas proportional counter survey instrument, is approximately $2,220,000 \mathrm{dpm}$ of beta activity.

\section{ENRICHED-URANIUM CONTAMINATION}

Because the primary hazard from enriched uranium (EU) is alpha radioactivity, the resulting beta skin dose is negligible. For EU process areas, not exceeding the alpha personnel contamination limits ensures that the beta personnel contamination limits have not been exceeded. Thus, the need to routinely survey EU workers for beta contamination is eliminated. Therefore, the levels of skin contamination that trigger the need for beta dose assessments for EU contamination must be based on alpha contamination levels. A list of assumptions that will be used to determine the 100-mrem skin-dose-assessment trigger level for EU skin contamination at the Y-12 Plant follows:

Radionuclides

Skin thickness

Size of contaminated area

Exposure time

EU isotopic abundances

${ }^{234 m} \mathrm{~Pa}$

${ }^{234} \mathrm{Th}$

${ }^{238} \mathrm{U}$

${ }^{231} \mathrm{Th}$

${ }^{235} \mathrm{U}$

Specific activity of ${ }^{238} \mathrm{U}$

Specific activity of ${ }^{235} \mathrm{U}$
${ }^{234 \mathrm{~m}} \mathrm{~Pa}$ and ${ }^{234} \mathrm{Th}$ (in equilibrium with ${ }^{238} \mathrm{U}$ )

${ }^{231} \mathrm{Th}$ (in equilibrium with ${ }^{235} \mathrm{U}$ )

$0.007 \mathrm{~cm}$

$20 \mathrm{~cm}^{2}$

$2 \mathrm{~h}$

$93 \%{ }^{235} \mathrm{U}, 6 \%{ }^{238} \mathrm{U}, 1 \%{ }^{234} \mathrm{U}$

$21 \mathrm{mrem} / \mathrm{h}$ per $100,000 \mathrm{dpm}$

$2 \mathrm{mrem} / \mathrm{h}$ per $100,000 \mathrm{dpm}$

$23 \mathrm{mrem} / \mathrm{h}$ per $100,000 \mathrm{dpm}$ (from ${ }^{234 \mathrm{~m}} \mathrm{~Pa}+{ }^{234} \mathrm{Th}$ betas)

$5 \mathrm{mrem} / \mathrm{h}$ per $100,000 \mathrm{dpm}$

$5 \mathrm{mrem} / \mathrm{h}$ per $100,000 \mathrm{dpm}\left({ }^{231} \mathrm{Th}\right.$ betas)

$0.333 \mu \mathrm{Ci} / \mathrm{g} \approx 7.39 \times 10^{5} \mathrm{dpm} / \mathrm{g}$

$2.14 \mu \mathrm{Ci} / \mathrm{g}=4.75 \times 10^{6} \mathrm{dpm} / \mathrm{g}$

The alpha specific activity of EU $\left(93 \%{ }^{235} \mathrm{U}\right)$ is

$$
\text { Alpha specific activity }=\left(0.4+0.38 E+0.0034 E^{2}\right) 10^{-6} \mathrm{Ci} / \mathrm{g} \text {, }
$$


where $E=$ wt $\%{ }^{235} \mathrm{U}$. [Equation (13) was taken from the Health Physics Manual of Good Practices for Uranium Facilities. $\left.{ }^{9}\right]$

The specific activity of EU is $65.1 \mu \mathrm{Ci} / \mathrm{g}\left(\approx 1.45 \times 10^{8} \mathrm{dpm} / \mathrm{g}\right)$. The ${ }^{235} \mathrm{U}$ alpha activity component in EU is calculated by

$$
\begin{aligned}
\frac{\mathrm{dpm}{ }^{235} \mathrm{U}}{\mathrm{dpm} E U} & =\frac{\text { specific activity of }{ }^{235} \mathrm{U}}{\text { specific activity of } \mathrm{EU}} \frac{\mathrm{g} \text { of }{ }^{235} \mathrm{U}}{\mathrm{g} \text { of } \mathrm{EU}} \\
& \approx \frac{4.75 \times 10^{6} \frac{\mathrm{dpm}{ }^{235} \mathrm{U}}{\mathrm{g} \text { of }{ }^{235} \mathrm{U}}}{1.45 \times 10^{8} \frac{\mathrm{dpm} \mathrm{EU}}{\mathrm{g} \mathrm{of} \mathrm{EU}}} \frac{93 \mathrm{~g} \text { of }{ }^{235} \mathrm{U}}{100 \mathrm{~g} \text { of } \mathrm{EU}} \\
& \approx 0.030 \frac{\mathrm{dpm}{ }^{235} \mathrm{U}}{\mathrm{dpm} \mathrm{EU}} \\
& \approx 3.0 \times 10^{3} \frac{\mathrm{dpm}{ }^{235} \mathrm{U}}{100,000 \mathrm{dpm} \mathrm{EU}}
\end{aligned}
$$

Likewise, for ${ }^{238} \mathrm{U}$,

$$
\begin{aligned}
\frac{\mathrm{dpm}{ }^{238} \mathrm{U}}{\mathrm{dpm} \mathrm{EU}} & \approx \frac{7.39 \times 10^{5} \frac{\mathrm{dpm}{ }^{238} \mathrm{U}}{\mathrm{g} \mathrm{of}{ }^{238} \mathrm{U}}}{1.45 \times 10^{8} \frac{\mathrm{dpm} \mathrm{EU}}{\mathrm{g} \mathrm{of} \mathrm{EU}}} \frac{6 \mathrm{~g} \text { of }{ }^{238} \mathrm{U}}{100 \mathrm{~g} \mathrm{of} \mathrm{EU}} \\
& \approx 3.06 \times 10^{-4} \frac{\mathrm{dpm}{ }^{238} \mathrm{U}}{\mathrm{dpm} \mathrm{EU}} \\
& \approx 30.6 \frac{\mathrm{dpm}^{238} \mathrm{U}}{100,000 \mathrm{dpm} \mathrm{EU}} .
\end{aligned}
$$

Therefore, the beta skin dose conversion factor for $\mathrm{EU}$ is

$$
\begin{aligned}
\frac{\beta \mathrm{mrem} / \mathrm{h}}{100,000 \mathrm{dpm} \mathrm{EU}} \approx & {\left[\left(3 \times 10^{3} \frac{\mathrm{dpm}^{235 \mathrm{U}}}{100,000 \mathrm{dpm} \mathrm{EU}}\right)\left(5 \frac{\mathrm{mrem} / \mathrm{h}}{100,000 \mathrm{dpm}{ }^{235} \mathrm{U}}\right)\right] } \\
& +\left[\left(30.6 \frac{\mathrm{dpm}^{238} \mathrm{U}}{100,000 \mathrm{dpm} \mathrm{EU}}\right)\left(23 \frac{\mathrm{mrem} / \mathrm{h}}{100,000 \mathrm{dpm}{ }^{238} \mathrm{U}}\right)\right] \\
& \approx 0.157 \frac{\mathrm{mrem} / \mathrm{h}}{100,000 \mathrm{dpm} \mathrm{EU}} .
\end{aligned}
$$


To incorporate the reporting requirements of DOE Order 5480.11 and DOE N 5480.6 into the trigger level for a 20-cm2 contaminated area, the dose averaged over the $1 \mathrm{~cm} 2$ of skin receiving the maximum dose must be reduced by the fraction $(f)$ that is the size of the contaminated area divided by $100 \mathrm{~cm} 2$. Therefore,

$$
\text { Reported dose of } 100 \mathrm{mrem}=\text { dose averaged over } 1 \mathrm{~cm}^{2} \frac{20 \mathrm{~cm}^{2}}{100 \mathrm{~cm}^{2}} \text {, }
$$

and

$$
\text { Dose averaged over } 1 \mathrm{~cm}^{2}=\frac{\text { reported dose of } 100 \mathrm{mrem}}{0.2}=500 \mathrm{mrem}
$$

The alpha contamination trigger level corresponding to a 500-mrem beta skin dose averaged over a $1-\mathrm{cm} 2$ area $\left(20-\mathrm{cm}^{2}\right.$ contaminated skin area) is

$$
\begin{aligned}
\text { Trigger level } & =\frac{\text { dose averaged over } 1 \mathrm{~cm}^{2} \text { of skin }}{\text { exposure duration }(\mathrm{h}) \times \text { dose conversion factor }(\mathrm{mrem} / \mathrm{h} \text { per } 100,000 \mathrm{dpm})} \\
& \approx \frac{500 \mathrm{mrem}}{2 \mathrm{~h} \frac{0.157 \mathrm{mrem} / \mathrm{h}}{100,000 \mathrm{dpm}}} \\
& =159,236,000 \mathrm{dpm} .
\end{aligned}
$$

With the use of the previously defined assumptions, the EU alpha contamination level that will correspond to a 100-mrem beta skin dose is approximately $159,236,000 \mathrm{dpm}$. 


\section{REFERENCES}

1. R. J. Traub, W. D. Reece, R. I. Scherpelz, and L. A. Sigalla, Dose Calculation for Contamination of the Skin Using the Computer Code VARSKIN, NUREG/CR-4418, U.S. Nuclear Regulatory Commission, Washington, D.C., August 1987.

2. U.S. Department of Energy, U.S. Department of Energy Radiological Control Manual, DOE N 5480.6, Washington, D.C., December 1992.

3. U.S. Department of Energy, Radiation Protection for Occupational Workers, DOE Order 5480.11, Washington, D.C., December 1988.

4. Title 10, Code of Federal Regulations, Pt. 835, "Radiation Protection for Occupational Workers," December 14, 1993.

5. M. J. Berger, "Distribution of Absorbed Dose Around Point Sources of Electrons and Beta Particles in Water and Other Media," Medical Internal Radiation Dose Committee Pamphlet No. 7, J. Nucl. Med., 12(5), 5 (1971).

6. International Commission on Radiological Protection, Recommendations of the Internal Commission on Radiological Protection, ICRP Publication 26, Annals of the ICRP, Vol. 1, No. 3, Pergamon Press, New York.

7. International Commission on Radiological Protection, Report of the Task Group on Reference Man, ICRP Publication 23, Pergamon Press, New York.

8. Martin Marietta Energy Systems, Inc., Centralized External Dosimetry System Procedure Manual, Procedure CEDS 5-1-05, Rev. 0, May 10, 1991.

9. Health Physics Manual of Good Practices for Uranium Facilities, DE88-013620, National Technical Information Service, U.S. Department of Commerce, Springfield, Va. 22161, June 1988. 


\title{
APPENDIX
}

\section{SAMPLE VARSKIN DATA FILE}

\author{
Program VARSKIN \\ MOD 1
Disc Source with Radius $=.56420 \mathrm{~cm}$
Skin Thickness $=.00700 \mathrm{~cm}$

\section{SOURCE}

$$
\begin{array}{rlc}
\text { Radionuclide } & : & \text { Pa-234M } \\
\text { Average Beta Energy (MeV) } & : & .864 \\
\text { X-90 Distance (cm) } & : & .5178 \\
\text { Srce Strength, microci/cm2 } & : & 4.50 \mathrm{E}-03 \\
\text { Irradiation time } & = & 3600 . \mathrm{sec} .
\end{array}
$$

AII cell damage occurs in an area with radius $=1.496 \mathrm{~cm}$

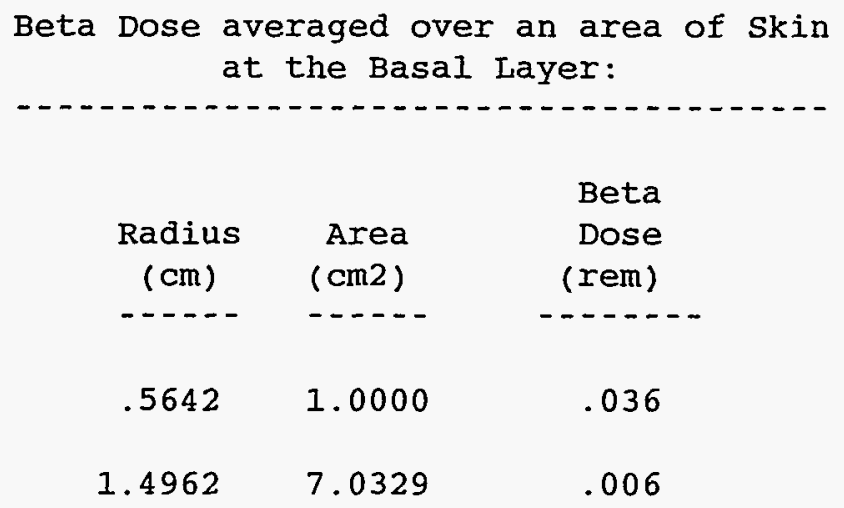


Calculated Beta Doses at Points on the skin Basal Layer:

$\begin{array}{cc}\begin{array}{c}\text { Horizontal } \\ \text { Distance } \\ (\mathrm{cm})\end{array} & \begin{array}{c}\text { Beta } \\ \text { Dose } \\ \text { (rem) }\end{array} \\ . .0000 & -. .-1 \\ .0451 & .041 \\ .0901 & .041 \\ .1724 & .041 \\ .2468 & .041 \\ .3134 & .040 \\ .3722 & .040 \\ .4231 & .039 \\ .4662 & .037 \\ .5015 & .034 \\ .5289 & .034 \\ .5485 & .032 \\ .5603 & .027 \\ .5642 & .022 \\ .5707 & .019 \\ .5901 & .015 \\ .6225 & .009 \\ .6678 & .005 \\ .7260 & .003 \\ .7972 & .002 \\ .8813 & .001 \\ .9784 & .000 \\ 1.0885 & .000 \\ 1.2114 & .000 \\ 1.3474 & .000 \\ 1.4962 & .000 \\ & \end{array}$




\section{Program VARSKIN}

MOD 1

$$
\begin{aligned}
\text { Disc Source with Radius } & =.56420 \mathrm{~cm} \\
\text { Skin Thickness } & =.00700 \mathrm{~cm}
\end{aligned}
$$

$\underline{\text { SOURCE }}$

$$
\begin{array}{rlc}
\text { Radionuclide } & : & \text { Th-234 } \\
\text { Average Beta Energy (MeV) } & : & .043 \\
\text { X-90 Distance (cm) } & : & .0094 \\
\text { Srce Strength, microci/cm2 } & : & 4.50 \mathrm{E}-03 \\
\text { Irradiation time } & = & 3600 . \mathrm{sec} .
\end{array}
$$

All cell damage occurs in an area with radius $=\quad .580 \mathrm{~cm}$

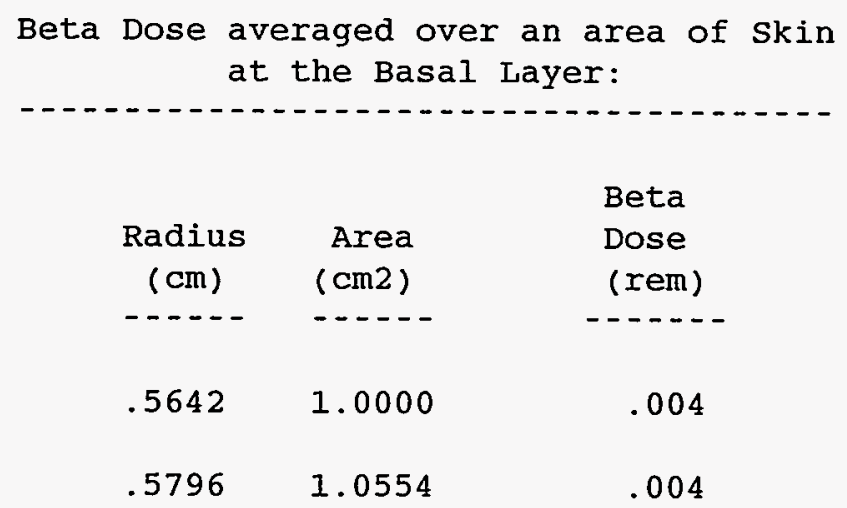


Calculated Beta Doses at Points on the Skin Basal Layer:

$\begin{array}{cc}\begin{array}{c}\text { Horizontal } \\ \text { Distance } \\ \text { (cm) }\end{array} & \begin{array}{l}\text { Beta } \\ \text { Dose } \\ \text { (rem) }\end{array} \\ . .5000 & -. .-1 \\ .000 & .004 \\ .5488 & .004 \\ .5513 & .004 \\ .5535 & .004 \\ .5555 & .004 \\ .5574 & .004 \\ .5590 & .003 \\ .5603 & .003 \\ .5615 & .003 \\ .5625 & .003 \\ .5632 & .002 \\ .5638 & .002 \\ .5641 & .002 \\ .5642 & .002 \\ .5643 & .002 \\ .5646 & .002 \\ .5652 & .002 \\ .5659 & .001 \\ .5669 & .001 \\ .5681 & .001 \\ .5694 & .001 \\ .5710 & .000 \\ .5729 & .000 \\ .5749 & .000 \\ .5771 & .000 \\ .5796 & .000 \\ & \end{array}$




\section{Program VARSKIN}

MOD 1

$$
\begin{aligned}
\text { Disc Source with Radius } & =.56420 \mathrm{~cm} \\
\text { Skin Thickness } & =.00700 \mathrm{~cm}
\end{aligned}
$$

\section{$\underline{\text { SOURCE }}$}

$$
\begin{array}{rlc}
\text { Radionuclide } & : & \text { Th-231 } \\
\text { Average Beta Energy (MeV) } & : & .065 \\
\text { X-90 Distance (cm) } & : & .0267 \\
\text { Srce Strength, microci/cm2 } & : & 4.50 \mathrm{E}-03 \\
\text { Irradiation time } & = & 3600 . \mathrm{sec} .
\end{array}
$$

All cell damage occurs in an area with radius $=\quad .612 \mathrm{~cm}$

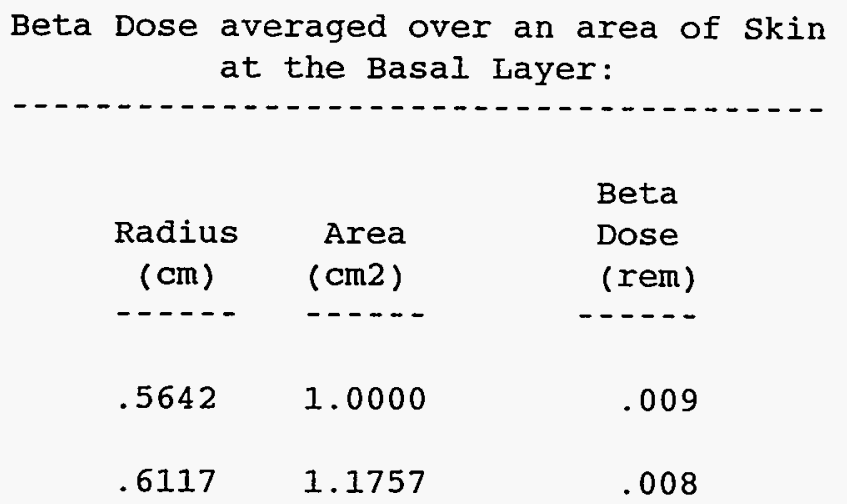




\begin{tabular}{cc}
$\begin{array}{c}\text { Calculated Beta Doses at Points } \\
\text { on the Skin Basal Layer: } \\
\text { Horizontal } \\
\text { Distance } \\
\text { (cm) }\end{array}$ & Beta \\
\hline & Dose \\
& (rem) \\
.0000 &.--10 \\
.5167 & .010 \\
.5242 & .010 \\
.5312 & .010 \\
.5375 & .010 \\
.5431 & .010 \\
.5480 & .009 \\
.5523 & .009 \\
.5559 & .009 \\
.5589 & .008 \\
.5612 & .008 \\
.5629 & .006 \\
.5639 & .006 \\
.5642 & .005 \\
.5645 & .005 \\
.5655 & .005 \\
.5672 & .004 \\
.5695 & .003 \\
.5725 & .002 \\
.5761 & .001 \\
.5804 & .001 \\
.5853 & .000 \\
.5909 & .000 \\
.5972 & .000 \\
.6042 & .000 \\
.6117 & .000 \\
&
\end{tabular}




\section{Distribution}

1. R. S. Bogard

2. B. G. Bowers

3. K. W. Branum

4. S. W. Croslin

5. C. A. England

6. G. R. Galloway

7. B. T. Gose

8. R. W. Gunter

9. HSEA Document Center

10. J. B. Hunt

11. R. M. Keyser

12. A. K. Lee - DOE/OSTI (2)

13. K. L. McMahan

14. G. T. Mei

15. J. A. Mohrbacher

16. R. N. Ortiz

17. D. P. Rowan

18. B. F. Rutherford

19. L. J. Schwanke

20. K. R. Shaw

21. L. M. Snapp

22. M. L. Souleyrette

23. J. M. Thomas (10)

24. Y-12 Plant Central Files

25. Y-12 Plant Records - RC 